\title{
A Preliminary Prospective Study for Seroprevalance of Hepatitis B Positivity in Hospital-Based Population from Bundelkhand Region of Uttar Pradesh
}

\author{
Varad Vardhan Bisen ${ }^{*}$ and Dwijendra Nath \\ Department of Pathology, Banda Medical College, Banda (UP)-210001, India
}

*Corresponding author: Varad Vardhan Bisen, Assistant Proffesor, Department of Pathology, Banda Medical College, Banda (UP)-21000, India, Tel: 093079 54926; E-mail: varadbisen@yahoo.co.in

Received date: April 18, 2018; Accepted date: July 25, 2018; Published date: August 10, 2018

Copyright: (C) 2018 Bisen VV, et al. This is an open-access article distributed under the terms of the Creative Commons Attribution License; which permits unrestricted use; distribution; and reproduction in any medium; provided the original author and source are credited.

\section{Abstract}

Background and Objective: The prevalence of infection often varies with geographical location. The aim of present study was to establish sero-prevalence of hepatitis B surface antigen among hospital based population in Bundelkhand region of Uttar Pradesh.

Methodology \& Study group: The study included a total of 1800 cases, which were enrolled in the out-patient department of Government Medical College, Banda from January 2017 to August, 2017. All serum samples were screened for hepatits B surface antigen (HBsAg) using rapid card method.

Results: Of the tested 1800 samples, a total of thirty-eight $(2.11 \%)$ cases were found positive for hepatitis B surface antigen. Majority positive cases were in the age groups of $21-30$ and $31-40$, both having $23 \%$ and $21 \%$ positivity respectively. Out the total 38 positive cases,25 cases were males (65\%) and 13 cases were females (35\%).

Conclusion: The study throws light on the magnitude of viral transmission in the rural community in Banda district of Uttar Pradesh state and provides a reference for future studies with a focus in rural areas.

Keywords: Hepatitis B; Hepatitis B surface antigen; Bundelkhand; Seroprevalence; Hospital based population.

\section{Introduction}

Viral hepatitis, a cause of significant morbidity and mortality in India, consists of five unrelated human pathogens. Among them, hepatitis B virus (HBV) infection remains a significant global health problem as a major cause of chronic liver disease (CLD) within creasing risk of cirrhosis and hepatocellular carcinoma (HCC) (WHO Fact Sheet) [1]. Estimates of the World Health Organization (WHO) suggest that more than 2 billion people worldwide have been infected with HBV. Of these, approximately 240 million individuals have chronic (long-term) liver infections and at risk of serious illness and death, mainly from liver cirrhosis and hepatocellular carcinoma (HCC). More than 780,000 people die every year due to the acute or chronic consequences of Hepatitis B [1,2].

Based on the prevalence of Hepatitis B surface antigen (HBsAg) different areas of the world are classified as having high $(\geq 8 \%)$, intermediate $(2-7 \%)$ or low $(<2 \%) \mathrm{HBV}$ endemicity. It has been found to be highest in sub-Saharan Africa and East Asia, where between $5-10 \%$ of the adult population is chronically infected. High rates of chronic infections are also found in the Amazon and the southern parts of eastern and central Europe. In the Middle East and the Indian subcontinent, an estimated $2-5 \%$ of the general population is chronically infected. Less than $1 \%$ of the population in Western Europe and North America is chronically infected $[1,3]$.
Being second most populous country with one-fifth of the world's population, India accounts for a very large proportion of the HBV burden [4]. The country harbors almost $10-15 \%$ of all HBV carriers of the world and estimated to be home to around 40 million HBV carriers. About $15-25 \%$ of the carriers may develop cirrhosis and liver cancer and die prematurely. The infant and childhood infections are most likely to become chronic [5]. Of the 2.6 crore (26 million) infants born every year in India, approximately 10 lakhs ( 1 million) run the life-time risk of developing chronic HBV infection [6]. Such factors make it imperative to study the prevalence of disease in populations. Therefore, an observational study was planned in the Banda district of Bundelkhand region, which has predominantly rural population to assess the prevalence and various risk factors.

\section{Materials and Methods}

\section{Study area and population}

The study was carried out from January, 2017 to August, 2017 for a period of 8 months at Government Medical College (a tertiary care hospital) in Banda district of Uttar Pradesh. All subjects visiting the out-patient department of the medical college and advised for HBsAg test, were included. The samples were collected for test at the central pathology laboratory of Government Medical College. Detailed information including demographic details like age, gender, occupation etc. was also taken. 
Citation: Bisen VV, Nath D (2018) A Preliminary Prospective Study for Seroprevalance of Hepatitis B Positivity in Hospital-Based Population from Bundelkhand Region of Uttar Pradesh. J Trop Dis 6:265. doi: 10.4172/2329-891X.1000265

Page 2 of 4

\section{Specimen}

Approximately 2-3 ml venous blood sample was collected aseptically from all patients who came with lab requisitions for the testing of HBsAg. The blood was allowed to clot for $30 \mathrm{~min}$ at room temperature and the serum was separated as per standard method in use and tested immediately.

\section{Hepatitis B infection assessment}

HBsAg was determined using a commercially available rapid card method HyperCard (Reckon diagnostics). All serum samples which were reactive with the above test were rechecked in-house by a different rapid test, Crystal HBsAg (Span Diagnostics). Principle of the screening card test is based on one step immunochromatography sandwich ELISA. All the tests were performed in accordance with the manufacturer's instructions with adequate controls. The analytical sensitivity and accuracy of these qualitative immunoassays is as low as $0.5 \mathrm{mg} / \mathrm{ml}$ antigen in serum as per manufacturers' claims.

\section{Results}

A total of 1800 cases were screened for HBsAg in the Department of Pathology laboratory from a period of January, 2017 to August 2017. Overall, thirty-eight (38) cases were found to be positive of hepatitis B surface antigen ( $\mathrm{HBsAg}$ ) in the serum sample, which gives a total prevalence positivity rate of $2.1 \%$ (Table 1 ). The study group was further segregated according to gender and different age groups. The studied population was divided into nine different groups according to age, starting from $0-10$ to $>80$ years.

\begin{tabular}{|l|l|}
\hline Total Screened Serum Samples & Seroprevalance \\
\hline 1800 & 38 \\
\hline$\%$ seroprevalence & $2.11 \%$ \\
\hline
\end{tabular}

Table 1: Percent Positivity in total screened samples.

As represented in Figure 1, majority positive cases were observed in population between 21 to 40 years with nine cases $(24 \%)$ in the age group of 21-30 and eight cases (21\%) in that of 31-40 years. However, Table 2 represents the total number of cases reported with each age group, along with the percent positivity. As evident from the Table 2, though more than five hundred serum samples were analysed in the age group between 21 to 30 years; only nine patients were found to be positive for $\mathrm{HBs} \mathrm{Ag}$ (1.76\%); whereas higher percent positivity (3.2\%) was observed in the age group of 51-60 years (5/154). The gender wise analysis of the cases is also presented in Table 3 . Out of total 38 positive cases, $65.7 \%$ were males $(25 / 38)$ and rest 13 cases were females (34.2\%). Majority positive cases were found in 21-40 years age group in both males and females; however over all difference in percent positivity was the same in both genders with $2 \%$ positivity in each group.

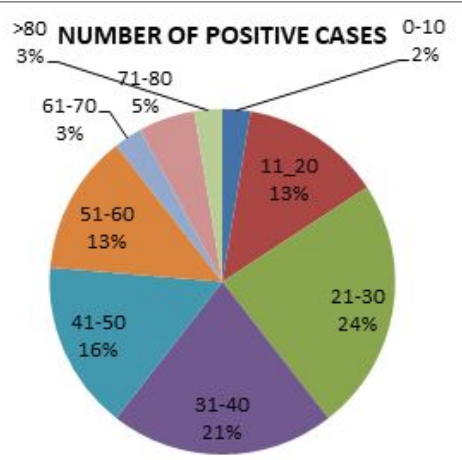

Figure 1: Age wise distribution and percent positivity in different age groups.

\begin{tabular}{|l|l|l|l|}
\hline Age & $\begin{array}{l}\text { No. of Sample } \\
\text { Tested }\end{array}$ & $\begin{array}{l}\text { HBsAg Positive } \\
\text { Patients }\end{array}$ & Percentage \\
\hline $0-10$ & 107 & 01 & 0.9 \\
\hline $11-20$ & 275 & 05 & 1.8 \\
\hline $21-30$ & 509 & 09 & 1.76 \\
\hline $31-40$ & 350 & 08 & 2.28 \\
\hline $41-50$ & 260 & 06 & 2.30 \\
\hline $51-60$ & 154 & 05 & 3.2 \\
\hline $61-70$ & 60 & 01 & 1.6 \\
\hline $71-80$ & 54 & 02 & 3.7 \\
\hline$>80$ & 31 & 01 & 3.2 \\
\hline
\end{tabular}

Table 2: Age wise distribution of total and HBsAg positive cases.

\begin{tabular}{|l|l|l|l|l|}
\hline Sex & Number of Sera Tested & $\begin{array}{l}\text { Number of Sera Tested Positive for } \\
\text { HBsAg }\end{array}$ & $\begin{array}{l}\text { Total Positive Percentage } \\
\text { (\%) }\end{array}$ & Percent Positivity \\
\hline Males & 1180 & 25 & $2.1(25 / 1180)$ & $65.7(25 / 38)$ \\
\hline Females & 620 & 13 & $2.0(13 / 620)$ & $34.2(13 / 38)$ \\
\hline
\end{tabular}

Table 3: Gender wise distribution of HbsAg positive patients.

\section{Discussion}

There is a wide variation in the prevalence of HBsAg in different regions of our country as represented in Table 4. The percent prevalence has been reported from 1 to $3 \%$ in different cities or states.
In a 2015-16 study done in Andhra Pradesh, 3\% prevalence of Hepatitis B has been reported [7]; whereas Quadri et al. [8] reported the prevalence of HBsAg to be $1.63 \%$, in a hospital based study at Bijapur, Karnataka. Seroprevalence in hospital based population was found to be $0.87 \%$ in Jaipur by Sood et al. [9]. Batham et al. [10] in 
Page 3 of 4

their review and meta-analysis on 61 populations of India concluded true prevalence of $2.4 \%$ in non-tribal population and $15.9 \%$ prevalence in tribal population. However, Lodha and his co-workers have concluded HBsAg prevalence of $1-2 \%$ in their study [11]. A prevalence of $1.67 \%$ among patients at a rural tertiary health care center in South India has also been reported [12].

The present study, conducted over a period of 8 months on a total of 1800 samples for Hepatitis B surface antigen reports a percentage prevalence of $2.11 \%$. Some other studies done in cities have found similar positivity, like $2.45 \%$ among twenty thousand blood donors of Kanpur city [13]; 2.31\% in OPD patients in Udaipur, Rajasthan [14] and 2.25\% in hospital based population in Karad, Maharasthra [15]. A study conducted by Dwivedi et al. [16] in Allahabad has found prevalence of $0.9 \%$ in pregnant females. All these studies approximately coincide with our study in terms of seroprevalence.

The prevalence of Hepatitis B varies from country to country and depends upon a complex mix of behavioral, environmental and host factors. In general, low prevalence is observed in countries with high standards of living e.g., Australia, North America or Europe and higher in countries with low socioeconomic levels such as South East Asia or South America. In a study conducted by Bhatta et al. [17] in hospitalbased population at Kathmandu Medical College Hospital, Nepal, the prevalence rate of viral Hepatitis B was found to be $2.5 \%$ [18]. The prevalence of $\mathrm{HBsAg}$ in patients attending a surgical OPD in Rawalpindi, Pakistan has been reported as $2.28 \%$ [19].

In our study total number of males screened was 1180 , out of which 25 were positive showing $2.11 \%$ positivity and total 620 were females, out of which 13 were positive showing $2.09 \%$ seroprevalence positivity. Thus a comparison of males and females out of total 38 positive cases, 25 were males whereas 13 were females. Our study shows no major difference between male and female prevalence positivity. One study by Alavian et al. [20] in West Iran found no major difference in seroprevalence among males and females [15]. However, most of the previous studies in India reported higher male prevalence viz. Sood et al. [9] reported HBsAg prevalence to be $1.04 \%$ and $0.58 \%$ respectively for males and females. Dutta et al. [18] have found $35.3 \%$ and $19.3 \%$ females. Singh et al. [21] have also noticed prevalence of $0.65 \%$ and $0.25 \%$ respectively in males and females in their study on blood donors, in which the prevalence was $0.62 \% 12$.

In the study, highest percentage of positive seroprevalence among all age groups was found to be in 51-60 years age group, which is due to less patients getting screened for HBsAg compared to more young patients getting routinely screened. However, out of total 38 patients found positive for HBsAg, majority were found in the age groups of 21-40 years. Vazhavandalet al. [12] in their study also found maximum number of patients in 21-40 age groups among the positive patients.

The patients attending the Government hospital are mostly rural to semi urban population of Bundelkhand region of Uttar Pradesh, which is considered to be one of the most backward regions of India. Thus our study highlights more HBV seroprevalence in rural population of Banda district and provides an important reference for future studies on the epidemiology of infection.

\begin{tabular}{|l|l|l|l|l|}
\hline $\begin{array}{l}\text { Place of } \\
\text { study }\end{array}$ & $\begin{array}{l}\text { Year of } \\
\text { study }\end{array}$ & $\begin{array}{l}\text { No. } \\
\text { samples } \\
\text { tested }\end{array}$ & $\begin{array}{l}\text { Study } \\
\text { population }\end{array}$ & $\begin{array}{l}\text { Prevalance } \\
(\%)\end{array}$ \\
\hline Jaipur & $2010-2011$ & 9515 & $\begin{array}{l}\text { General } \\
\text { population }\end{array}$ & 1.73 \\
\hline
\end{tabular}

\begin{tabular}{|l|l|l|l|l|}
\hline Bijapur & 2010 & 4283 & $\begin{array}{l}\text { General } \\
\text { population }\end{array}$ & 1.63 \\
\hline Vijaypur & $2013-2014$ & 15230 & Genralpopulation & 1.76 \\
\hline $\begin{array}{l}\text { Andhra } \\
\text { Pradesh }\end{array}$ & $2015-2016$ & 24028 & $\begin{array}{l}\text { General } \\
\text { population }\end{array}$ & 3.05 \\
\hline Punjab & $2013-2014$ & 3686 & Antenatal females & 1.11 \\
\hline Kanpur (UP) & $2002-2006$ & 20000 & Blood donors & 2.45 \\
\hline Banda (UP) & 2017 & 1800 & $\begin{array}{l}\text { General } \\
\text { population }\end{array}$ & 2.1 \\
\hline
\end{tabular}

Table 4: Comparison of Prevalence of HBV at Various Geographical Locations in India.

\section{Conclusion}

It is important to carry out larger studies to better elucidate the epidemiology of HBV and identify the high prevalence areas. The present study helps to know the magnitude of viral transmission in the community and to know the high risk age groups. Future surveillance studies warranting investigations for this viral infection in a broader population will help us to determine combating threats by Hep B virus. In addition, epidemiologic studies like the present ones from different states of India would be helpful to estimate real statistics of Hepatitis B infection in India.

\section{References}

1. World Health Organization. Hepatitis B. World Health Organization Fact Sheet No 204.

2. Lok AS (2002) Chronic hepatitis B. N Engl J Med 346: 1682-1683.

3. Goldstein ST, Zhou F, Hadler SC, Bell BP, Mast EE, et al. (2005) A mathematical model to estimate global hepatitis B disease burden and vaccination impact. Int J Epidemiol 34: 1329-1339.

4. Te HS, Jensen DM (2010) Epidemiology of hepatitis B and C viruses: A global overview. Clin Liver Dis 14: 1-21.

5. Operational guidelines for Hepatitis $B$ vaccine introduction in the universal immunization programme. Printed by World Health Organization on behalf of Ministry of health and family welfare, Govt of India 2011.

6. Puri P (2014) Tackling the Hepatitis B Disease Burden in India. J Clin Exp Hepatol 4: 312-319.

7. Bula A, Gaddam SR (2017) Seroprevalence of Hepatitis B surface antigen positive patients attending a tertiary care hospital in Srikakulam, Andhra Pradesh. Ann Patho Lab Med 4: 96-99.

8. Quadri SA, Dadapeer HJ, Arifulla M, Khan N (2013) Prevalence of Hepatitis B surface antigen in hospital based population in Bijapur, Karnataka. Al Ameen J Med Sci 6: 180-182.

9. Sood S, Malvankar S (2010) Seroprevalence of Hepatitis B surface antigen, antibodies to the Hepatitis $\mathrm{C}$ virus, and Human Immunodeficiency Virus in a hospital-based population in Jaipur, Rajasthan. Indian J Community Med 35: 165-169.

10. Batham A, Narula D, Toteja T, Sreenivas V, Puliyel JM (2007) Systematic review and meta-analysis of prevalence of Hepatitis B in India. Indian Pediatr 44: 663-674.

11. John TJ, Abraham P (2001) Hepatitis B in India: A review of disease epidemiology. Indian Pediatr 38: 1318-1325.

12. Vazhavandal G, Bharadwaj VGB, Uma A, Rajalakshmi CP (2014) Seroprevalence of hepatitis $B$ virus among patients at a rural tertiary health care centre in South India: A four year study. Int J Res Med Sci 2: 310-313. 
Citation: Bisen VV, Nath D (2018) A Preliminary Prospective Study for Seroprevalance of Hepatitis B Positivity in Hospital-Based Population from Bundelkhand Region of Uttar Pradesh. J Trop Dis 6:265. doi: 10.4172/2329-891X.1000265

Page 4 of 4

13. Behal R, Jain R, Behal KK, Bhagoliwal A, Aggarwal N, et al. (2008) Seroprevalence and risk factors for hepatitis $\mathrm{B}$ virus infection among general population in Northern India. Arq Gastroenterol 45: 137-140.

14. Sharma M, Bohra S, Mehra SK, Shah R (2017) Seroprevalence of Hepatitis B Virus Infection among OPD patients attending tertiary care Hospital. Int Arch BioMed Clin Res 3: 50-53.

15. Patil SR, Ghorpade MV, Patil SS, Pawar SK, Mohite ST (2016) Seroprevalence of Hepatitis-B surface antigen among the patients reporting at tertiary care Hospital from India. Bangl J Medi Sci 15: 455-459.

16. Dwivedi M, Misra SP, Misra V, Pandey A, Pant S, et al. (2011) Seroprevalence of hepatitis $B$ infection during pregnancy and risk of perinatal transmission. Indian J Gastroenterol 30: 66-71.

17. Bhatta CP, Thapa B, Rana BB (2010) Seroprevalence of hepatitis "B" in Kathmandu Medical College Teaching Hospital (KMCTH). Kathmandu Univ Med J (KUMJ) 1: 113-116.
18. Dutta S (2008) An overview of molecular epidemiology of hepatitis B virus (HBV) in India. Virol J 5: 156.

19. Chaudhary IA, Khan SS, Majrooh MA, Alvi AA (2007) Seroprevalence of hepatitis $\mathrm{B}$ and $\mathrm{C}$ among patients reporting in a surgical OPD at Fauji Foundation Hospital, Rawalpindi: Review of 5 year literature. Pak J Med Sci 23: 514-517.

20. Alavian SM (2010) Infectious diseases and tropical medicine research center hepatitis B virus infection in Iran: Changing the epidemiology. Iranian Journal of Clinical Infectious Diseases 5: 51-61.

21. Singh K, Bhat S, Shastry S (2009) Trend in seroprevalence of Hepatitis B virus infection among blood donors of coastal Karnataka, India. J Infect Dev Ctries 3: 376-379. 